\title{
The Harrod - Domar Growth Model and its Implications for Economic Development in Vietnam
}

\author{
Le Ngoc Thong*, Nguyen Thi Hao \\ Teacher at the National Economics University, Vietnam
}

*Corresponding Author: Le Ngoc Thong, Teacher at the National Economics University, Vietnam

\begin{abstract}
By synthesizing a suitable research methodology, the paper examines the basics of the HarrodDomar growth model and adds those model applications to the analysis of national economic development. Thereby, it is suggested to use Harrod-Domar model in the orientation of the national economy in Vietnam
\end{abstract}

Keywords: Harrod - Domar, ICOR, economic theory, economic growth and development model, economic development, economic growth, policy application, capital

\section{INTRODUCTION}

In the current context, the issue of economic growth and development is an urgent issue for developing countries. Vietnam is also in the vortex, where the use of theoretical models of growth is relatively new and difficult. But according to the requirements of international economic integration, the process is considered as an indispensable activity in policy making. Many models of economic growth must be considered, including the growth model Harrod-Domar.

\section{METHODOLOGY}

The paper uses a combination of methods: theoretical research, document research, practical research ... to perfect theories and draw scientific conclusions.

\section{RESEARCH RESULTS}

\subsection{The Inheritance in the Flow of History of Economic thought}

The history and development of theories of economic growth and development have gone through four stages: (i) From the 18th to the 50th centuries, the prevailing view of " Capital accumulation "with the classic growth model of A. Smith and growth model Harrod-Domar; (ii) From the late 1950s to the early 1960s, the prevailing view of the "technology" theory with the growth models of Robert Slow and Danison; (iii) From the late 1960s to the 70s of the twentieth century, the prevailing view of the "human capitalist" theory of the growth model of Theodore Schultz; (iv) To this day, the prevailing trend of "new growth" with the growth model of RomoRucas and Scost[6; 316].

Thus, at each stage there are the theories and the ability to adapt accordingly. In particular, attention is paid to applications from growth model Harrod-Domar.

Based on Keynesian ideas, in the 1940s, growth model Harrod-Domaremerged and was widely used in developing countries to examine the relationship between growth and capital needs.

Growth model Harrod-Domar "is a synthesis of the results of two consecutive independent studies by British economist Roy Harrod with the" Theory of Dynamic Theory "(1939) and the American economist Polish author EvseyDomar with "Capital Expansion, Growth and Jobs" (1946) "1.

The starting point for the construction $(\mathrm{H})$ is the viewpoint of J. Keynes.

The basic ideas of J. Keynes:

\footnotetext{
${ }^{1}$ Based on Document 1
} 
The notion of equilibrium below potential and the role of expenditure (aggregate demand): "The economy can reach and maintain a balance at a certain level of output" ${ }^{2}$. (see picture)

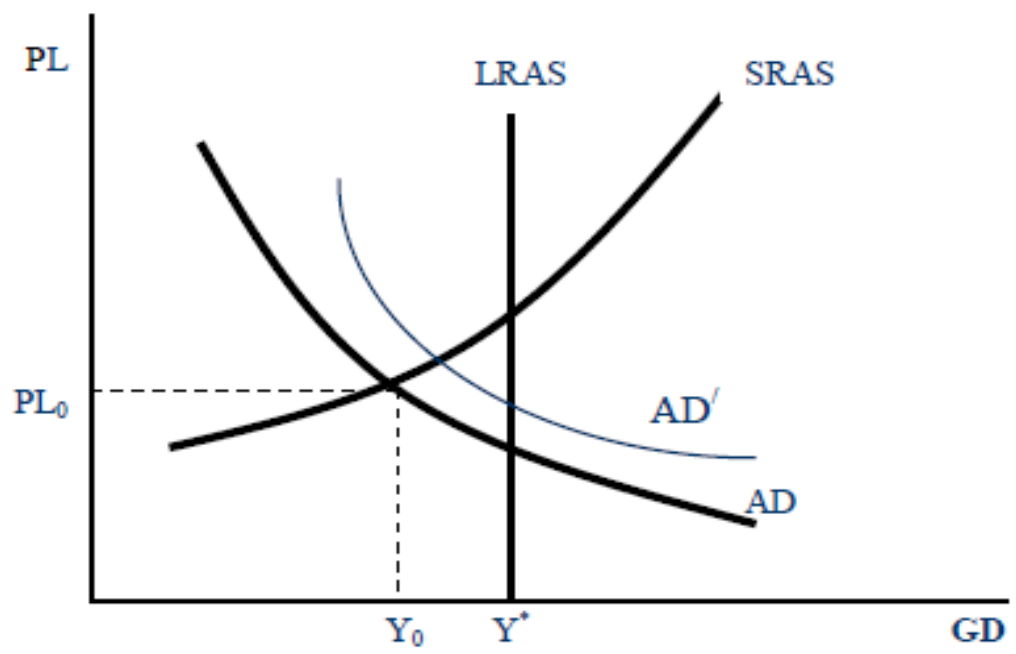

Fig1: Relations supply - demand

LRAS: Potential output level $\left(\mathrm{Y}^{*}\right)$

SRAS: Actual output level $\left(\mathrm{Y}^{\circ}\right)$

According to $\mathrm{J}$. Keynes, the balance of the economy is always below potential; Actual yield is $\mathrm{Y}^{\circ}<\mathrm{Y}$ *; The length $\left(\mathrm{Y}^{\circ}-\mathrm{Y}^{*}\right)$ is the recession of the economy.

J. Keynes appreciates the role of aggregate consumption factors. Increasing aggregate demand will reduce the recession, and the income of the economy will increase

- Investment ideas create income effect. According to J. Keynes, spending on investment plays the most positive role - generating revenue

More specifically, J. Keynes identifies investments with savings ( $\mathrm{S}=\mathrm{I}$ ); Investment decides the size of the job, and on the other hand, J. Keynes also points out that the investment volume depends on the loan interest rate and the marginal effectiveness of the amount of capital.

Hence, Harrod said that the growth rate of the economy depends on the total savings and the relationship between capital and output.

While Domar develops the idea of the role of expenditure for investment in "economic growth theory": Investment enhances the capacity of the economy $(\mathrm{I}=\Delta \mathrm{K})$. "Savings is the source of today's investment and investment, which is the basis of tomorrow's rising production capital and rising production plays a direct role in increasing the size of the income economy" ${ }^{3}$. At the same time, Harrod proposed the premise: (i) total savings by total investment; (ii) inputs K, L are variables; (iii) K-L graduation rate is constant; (iv) Population, technology and labor saving have a constant increase

\subsection{Harrod-Domar model on the role of resource factors in growth ${ }^{4}$}

\subsubsection{The Factors that Directly Affect Growth}

With the abstraction method, Harrod-Domar has fixed the technology, so economic growth depends on three factors: capital (K), labor (L), and resources (R)

$$
\mathrm{Y}=\mathrm{f}(\mathrm{K}, \mathrm{L}, \mathrm{R})
$$

$\mathrm{R}, \mathrm{L}$ are the resource factors used on the basis of creating an increase in production capital (K).

Here the relationship between growth and capital needs to be considered. Addressing this relationship needs to address the relationship between savings (S), investment (I), productive capital $(\mathrm{K})$ and production capacity $(\mathrm{Y})$. According to Harrod-Domar, the relationships are as follows:

\footnotetext{
${ }^{2}$ Based on Document2

${ }^{3}$ Based on Document 1

${ }^{4}$ Based on Document 7
} 
$+\mathrm{S}$ is the source of the investment (I)

+ I creates the $\Delta \mathrm{K}$ of the later period

$+\Delta \mathrm{K}$ directly creates $\Delta \mathrm{Y}$ of that period

The basic argument in this model is: Saving and investing creates increased capital and production capital is the source of economic growth or a determinant of economic growth. As capital changes, national output changes accordingly

$$
(\Delta \mathrm{K}) \Rightarrow(\Delta \mathrm{Y})
$$

Increased capital is due to investment activities: $\mathrm{I}=\mathrm{DK}$

\subsubsection{The Relationship between Capital Increase and Output}

For this relationship, one uses the ICOR(Incremental Capital - Output Rate) increment. Then,

$$
\mathrm{kt}(\mathrm{ICOR})=\Delta \mathrm{Kt} / \Delta \mathrm{Yt}
$$

- Factors affecting the ICOR: (i) Technical characteristics of production capital; (ii) Level of resource scarcity; (iii) effective management and use of capital; ...

\subsubsection{The Relationship between Growth Rate $(G)$ and Saving Rate $(S)$ and Investment (I)}

$$
\begin{gathered}
\mathrm{gt}=\Delta \mathrm{Yt} / \mathrm{Y}_{\mathrm{t}-1} \\
\mathrm{gt}=\Delta \mathrm{Kt} /\left(\mathrm{k} . \mathrm{Y}_{\mathrm{t}-1}\right) \\
\Delta \mathrm{Kt}=\mathrm{I}_{\mathrm{t}-1}=\mathrm{S}_{\mathrm{t}-1} \\
\mathrm{gt}=\mathrm{I}_{\mathrm{t}-1} /\left(\mathrm{k} . \mathrm{Y}_{\mathrm{t}-1}\right)=\mathrm{S}_{\mathrm{t}-1} /\left(\mathrm{kt} . \mathrm{Y}_{\mathrm{t}-1}\right)
\end{gathered}
$$

$\mathrm{s}$ is the cumulative rate in GDP and the cumulative level is $\mathrm{S}$ :

$$
\mathrm{s}=\mathrm{S} / \mathrm{Y} \text { should be } \mathrm{gt}=\mathrm{s}_{\mathrm{t}-1} / \mathrm{kt}
$$

Conclusions from the Harrod-Domar model:

Simultaneous economic growth with a saving rate and an inverse with the ICOR.

In other words: growth rate always depends on saving and ICOR.

Here are three growth rates:

- Guaranteed speed: $\mathrm{gw}=\mathrm{s}$ (expected) $/ \mathrm{k}$ (expected)

- Actual speed: $\mathrm{gr}=\mathrm{s}$ (expected) / $\mathrm{k}$ (actual)

- Natural speed (gf) in terms of reaching the potential level.

From that reasoning, in the growth model Harrod-Domar, it refers to the concept of the golden age:

$$
\mathrm{gW}=\mathrm{gr}=\mathrm{gf}
$$

That is the balance between the three growth rates mentioned above $\mathrm{e}^{5}$.

\subsection{Limitations of growth model Harrod-Domar}

1.4.1. Simplification in growth research, giving insufficient arguments: Economic growth is only due to investment and has ignored the following: (i) Inefficient investment will not lead to growth; (ii) Growth using alternative solutions without using investment solutions; (iii) Investments to a certain degree will be subject to a gradual decrease in income rules

1.4.2. Models that can not cope with difficulties in developing countries are difficult to cushion, which can have the following consequences: (i) the imbalance between accumulation and consumption; (ii) Dependent on loans; (iii) The government becomes a big debtor and risk of bankruptcy.

\footnotetext{
${ }^{5}$ Based on Document2
} 


\section{Policy applications of THE HaRrod-Domar MOdel in Vietnam}

\subsection{Modeling in Economic Growth Planning}

Apply the model in economic growth planning with the main contents: determine the growth target and the need for investment capital needed to achieve the set objectives.

* Guaranteed growth planning (gk) (determines growth targets)

$$
\mathrm{g}_{\mathrm{k}}=\mathrm{s}_{0} / \mathrm{kk}
$$

$\mathrm{g}_{\mathrm{k}}$ - Growth rate of the planned period

$\mathrm{s}_{0}$ - Original Savings Rate

kk - coefficient ICOR periodic plan

Steps to proceed:

Step1: ICOR forecasts, this step is conducted on the basis of the ICOR changes over the years, using the regression model, econometrics in combination with the forecasts on the development of the department. learn technology in the future and level of resource scarcity, resources, ... Often, there are many options for this coefficient.

Step2: Determine the ability to save the original, based on the economy savings (note: source of savings including source of savings from abroad);

There are two indicators to be taken into account: investment savings ( $\mu \mathrm{s}=$ Io / So) and capital return factor $(\mu \mathrm{i}=\Delta \mathrm{kk} / \mathrm{Io})$

Then $\mathrm{s}_{0}($ real $)=\mathrm{s}_{0}($ in the base period $) . \mu \mathrm{s} .(1-\mu \mathrm{i})$

Step3: Calculate the guaranteed growth plans.

$$
\mathrm{gk}=\mathrm{So} / \mathrm{kk}
$$

Example: $\mathrm{ICOR}=3, \mathrm{~s}=20 \%, \rightarrow \mathrm{gk}=20 / 3=6,7 \%$

Want to $\mathrm{gk}=11 \%$, ICOR constant $(=3) \rightarrow \mathrm{s}=\mathrm{gk} . \mathrm{kk}=11 \% .3=33 \%$

Step 4. Calculate guaranteed growth plans

* Determining the investment capital needed to achieve the set objectives

From the above: so $=\mathrm{k}$. gk

To ensure this content needs to:

- ICOR forecasts in different scenarios.

- Define the ability to save the original, based on the economy savings

There are two indicators to be taken into account: investment savings $(\mu \mathrm{s}=\mathrm{Io} / \mathrm{So})$ and capital return factor $(\mu \mathrm{i}=\Delta \mathrm{kk} / \mathrm{Io})$

Actually: $\mathrm{s}$ in the above formula is adjusted to:

$$
\mathrm{s}_{0}(\text { adjusted })=\mathrm{s}_{0} \times \mu \mathrm{s} \times(1-\mu \mathrm{i})
$$

The growth rate of the plan is determined:

$$
\mathrm{gk}=\left[\mathrm{s}_{0} \mathrm{x} \mu \mathrm{s} \times(1-\mu \mathrm{i})\right] / \mathrm{kk}
$$

Then compare $\mathrm{s}_{\mathrm{o}}($ real $)=\mathrm{s}_{\mathrm{o}}($ in the base period $) / \mu \mathrm{s}$. $(1-\mu \mathrm{i})$

Word on that may be happen 2 school

$+\mathrm{s}_{\mathrm{o}}(\mathrm{n} / \mathrm{c})>\mathrm{s}_{\mathrm{o}}(\mathrm{k} / \mathrm{n})$ : Excess capital compared to demand. If so, increase the growth target; using technology with higher capital; investment abroad, ...

$+\mathrm{s}_{\mathrm{o}}(\mathrm{n} / \mathrm{c})<\mathrm{s}_{\mathrm{o}}(\mathrm{k} / \mathrm{n})$ : Often happens to developing countries; lack of capital compared to demand. If so, there should be solutions to mobilize more capital, from domestic savings; from foreign direct investment, indirect; lowering ICOR by restructuring labor-intensive sectors and reducing capitalintensive industries; 


\subsection{Use the Macro Regulation Policy to Implement the Sustainable Growth Plan}

Overall, "developing country governments need to use timely macroeconomic regulatory instruments to stabilize aggregate demand in order to achieve the set economic growth target"6

\subsubsection{Government's Activities Aim to Increase Economic Growth}

\subsubsection{General Requirements for the Operation of the Government}

Government policymakers should understand the principle

(i) Policy development must ensure that: Rapid economic growth; Equality and social justice are enhanced; Growth does not negatively affect the rich-poor divide.

(ii) Perform the tasks: Determining the economic growth target for the new period when determining the saving capacity of the original economy and predicting the ICOR of the planned period is one of the important grounds for the planners. Planning for the development of economic and social development; In the face of a growth target set by the leaders, the model allows us to identify the cumulative need to achieve that goal. The basis for assessing the possibility of achieving the set goals.

Under the Harod-Domar growth model, the economic growth plan is established on the basis of expected savings and expected ICOR. But the fact that the factors that affect aggregate demand fluctuate cause aggregate demand to increase or decrease

+ If the aggregate demand trend increases: the production facilities will fully exploit the production capacity, first of all the assets. This makes the ICOR coefficient decrease, the actual increase is higher. At the same time, due to increased demand, manufacturers continue to increase investment, ... the economy will fall into boom.

As aggregate demand decreases, investment will fall, although not offset, the economy will fall into recession, unemployment and the loss of other resources.

In any situation, governments in developing countries need to use timely macroeconomic regulatory instruments to stabilize aggregate demand.

\subsection{Government's Activities Aim to Increase Economic Growth}

a. Government activities as aggregate demand increases: Fiscal and fiscal policies must be tightened, making the investment, consumption and export markets more limited, and the output will be expanded, the economy going into stable growth as scheduled.

Illustrate the use of the Harod-Domar model in Vietnam

To fight recession, stabilize growth, Vietnam has implemented two policies. Fiscal policy is the policy of the government to influence the development orientation of the economy through changes in government spending and taxes; Monetary policy mainly focuses on monetary stability (control of inflation); economic growth; job creation and balance of payments. Fiscal policy and monetary policy in controlling inflation in Vietnam in recent years.

In fact, Vietnam, despite difficulties, in 2017 economic growth reached $6.81 \%$, exceeding the target $6.7 \%$, the highest in 10 years

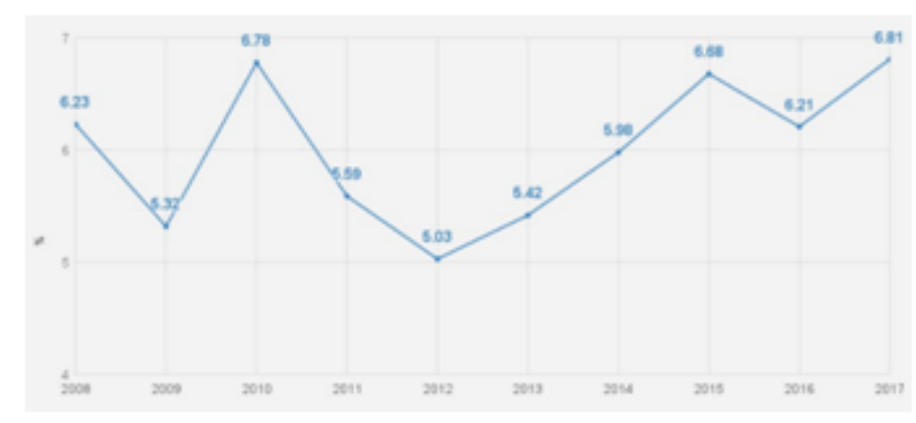

Fig2: Vietnam's economic growth rate from $2008-2017^{7}$

${ }^{6}$ Based on Document1 
In investment, ICOR in 2017 reached 4.93, in 2016 reached 5.15. ICOR tends to decrease, investment efficiency of the economy gradually improved.

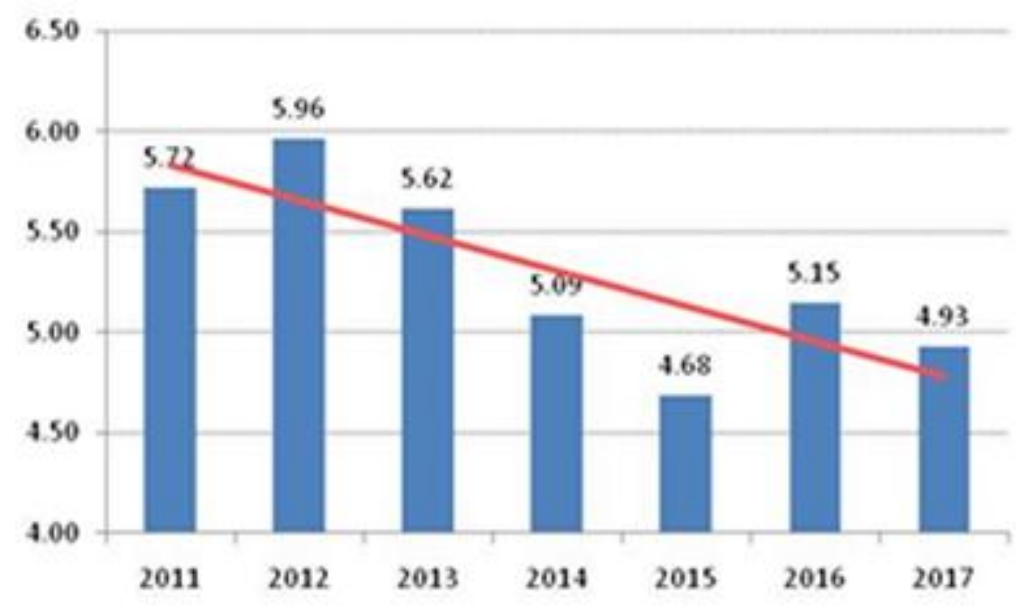

Fig3: ICOR of the economy for the period $2011-2017^{8}$.

Actually, Vietnam must perform the task of "stabilizing the macro economy and curbing inflation. ..., the government must reduce the aggregate demand of the economy, reduce credit, money supply, public spending through fiscal and monetary policy adjustments, and adjust the exchange rate by $9.3 \%$ over the past few years, the state is a logical step"

\section{b. Government activities as aggregate demand decreases.}

In case the economy shows signs of recession, the government should implement loose fiscal and monetary policies, lower interest rates and adjust corporate income tax reductions. Thereby contributing to boosting the scale of production, expanding investment, restoring the economy in the direction of stability

Illustrate the use of the Harod-Domar model in Vietnam

"Resolving the consequences of the global financial crisis, the government has implemented the following: fiscal policy expansion; monetary policy where liquidity is controlled; indirectly stimulating demand on the stock market;

\section{COMMENTS AND CONCLUSIONS}

In today's world, "the rich and poor gap between nations is getting deeper and deeper. Many countries are in danger of lagging behind in terms of economics compared with developed countries. Therefore, the issue of economic growth and development is an urgent issue for these countries"10. In Vietnam, the use of theoretical models of growth is relatively new and difficult. But according to the requirements of international economic integration, the process is considered as an indispensable activity in policy making.

\section{REFERENCES}

[1] Dwight H. Perkins et al. Translation: Kim Chi; The Economics of Development - 6th ed. Chapter 4: Theories of Economic Growth Fulbright Economics Teaching Program

[2] Development economics curriculum, NEU, Labor and Social Publishing House, 2005.

[3] Th.sKhuatDuy Tuan; Discuss the coordination between fiscal policy and monetary policy. Posted on www.sbv.gov.vn

[4] PTT Nguyen Sinh Hung; The government will tighten monetary and fiscal policy (Report presented in Parliament). Posted on VN Economy on 21/3/2011.

\footnotetext{
${ }^{7}$ Source: General Statistics Office

${ }^{8}$ Based on Document(TS. Pham SyAn, Vietnam's Economics 2017 and Prospects 2018: Growth on a solid foundation, Posted on http://vietnamnet.vn/vn/kinh-doanh/dau-tu/kinh-te-viet-nam-2017-va-trien-vong-2018tang-truong -tren-nen-tang-vung-chac-421275.html 18.9.2018)

${ }^{9}$ Based on Document5

${ }^{10}$ Based on Document6
} 
[5] Adjusting the exchange rate is a reasonable step. Posted on www.tinmoi.vn on 9/3/2011.

[6] Assoc. Tran BinhTrong, History of economic theory, Statistics Publishing House, HN 2003.

[7] Growth model Harrod - Domar, posted on https://toc.123doc.org/document/646126-ii-mo-hinh-tangtruong-harrod-domar.htm

\section{AUTHORS' Biography}

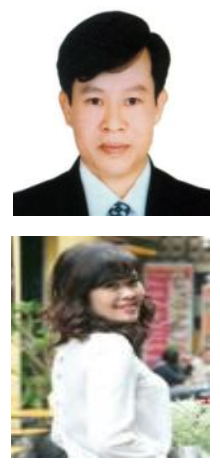

Le Ngoc Thong, Doctor; Born on July 10, 1958 in Ninh Binh, Vietnam. Department of Political Theory, National Economics University, Ha Noi, Vietnam. Research fields are Economics, Political Economics, History of economics Theories, and Philosophy.

Nguyen Thị Hao, Doctor, Born on April 18, 1976 in Nam Dinh, Vietnam. Department of Political Theory, National Economics University, Ha Noi, Vietnam. Research fields are Economics, Political Economics, History of economics Theories, and Philosophy.

Citation: Le Ngoc Thong, Nguyen Thi Hao. "The Harrod - Domar Growth Model and its Implications for Economic Development in Vietnam" International Journal of Humanities Social Sciences and Education (IJHSSE), vol 6, no. 4, 2018, pp. 11-17. doi: http://dx.doi.org/10.20431/2349-0381.0604003.

Copyright: (C) 2018 Authors. This is an open-access article distributed under the terms of the Creative Commons Attribution License, which permits unrestricted use, distribution, and reproduction in any medium, provided the original author and source are credited. 